\title{
First record of Cochlodinium convolutum and C. helicoides (Gymnodiniales: Dinophyceae) in the Gulf of California
}

\author{
Primer registro de Cochlodinium convolutum y C. helicoides \\ (Gymnodiniales: Dinophyceae) en el Golfo de California
Ismael Gárate-Lizárraga ${ }^{1}$, Federico García-Domínguez ${ }^{1}$, Beatriz Pérez-Cruz ${ }^{2}$ and Jesús Antonio Díaz-Ortiz ${ }^{2}$

\begin{abstract}
${ }^{1}$ Centro Interdisciplinario de Ciencias Marinas, Instituto Politécnico Nacional, Apartado postal 592, C.P. 23096, La Paz, B.C.S., México.igarate@ipn.mx

${ }^{2}$ Laboratorio Estatal de Salud Pública 'Dr. Galo Soberón y Parra', Boulevard Vicente Guerrero, Esq. Juan R. Escudero s/n, Ciudad Renacimiento, Acapulco, Guerrero, México
\end{abstract}

\begin{abstract}
The naked marine dinoflagellates Cochlodinium convolutum and $C$. helicoides are reported for the first time in the Gulf of California. They occurred in seawater at $21-24.5^{\circ} \mathrm{C}$. Cochlodinium convolutum was found in both bottle and net samples; its abundance ranged from 400-2200 cells $\mathrm{L}^{-1}$. A total of 96 specimens of $C$. convolutum and 23 specimens of $C$. helicoides were examined from the net phytoplankton samples. A short description is given for each species, and photomicrographs provide information about the main morphological characteristics.
\end{abstract}

Key words: Dinoflagellates, phytoplankton, Mexico

\section{INTRODUCTION}

The genus Cochlodinium belongs to the order Gymnodiniales Lemmermann, 1910. Cochlodinium is an unarmored, marine planktonic dinoflagellate genus forming cell chains with a distinctive spiral-shaped cingulum of 1.5 or more gyres around the cell. According to the recent world-wide review on marine dinoflagellates by Gómez (2005), there are 35 species of Cochlodinium. Cochlodinium fulvescens Iwataki, Kawami \& Matsuoka, 2007 was recently described as a new species (Iwataki et al. 2007). Most of the Cochlodinium species are heterotrophic or mixotrophic and have rarely been observed since their original descriptions (Iwataki et al. 2007, Gárate-Lizárraga et al. 2009a). Taxonomy and geographic distribution of Cochlodinium species have scarcely been studied in Mexico. Ten species of Cochlodinium have been found in Pacific coastal waters of Mexico (Gárate-Lizárraga et al. 2004, 2009a, 2009b, Cortés-Lara et al. 2004, Okolodkov \& Gárate-Lizárraga 2006, Morquecho-Escamilla \& Alonso-Rodríguez 2008). In these reports, massive blooms of Cochlodinium polykrikoides Margalef, 1961 have been recorded along the west coast (Gárate-Lizárraga et al. 2004, 2009b, Morales-Blake et al. 2001). Cochlodinium fulvescens blooms have also been recorded however only in the
Gulf of California (Morquecho-Escamilla \& AlonsoRodríguez 2008, Gárate-Lizárraga et al. 2009a). This report describes the presence of Cochlodinium convolutum Kofoid \& Swezy, 1921 and Cochlodinium helicoides Lebour, 1925 for the first time in the Gulf of California.

\section{Materials AND Methods}

Phytoplankton was sampled at a fixed sampling station in Bahía de La Paz, Baja California Sur, Mexico (242ำ $\mathrm{N}$, $110^{\circ} 31$ 'W) on 24 March 2011, 28 April 2011, 24 May 2011, and 26 June 2011. Two surface horizontal tows and two vertical hauls from $15 \mathrm{~m}$ were performed using a $20 \mu \mathrm{m}$ mesh net, $50 \mathrm{~cm}$ diameter. Each sample was immediately fixed with acid Lugol's solution and preserved with $4 \%$ formalin. Other set samples were used for live phytoplankton observations. Two samples were also collected during each sampling to estimate Cochlodinium abundance. Cell counts were made in $5 \mathrm{~mL}$ settling chambers under an inverted, phase-contrast microscope (Carl Zeiss, Germany). Sea surface temperature was recorded using a bucket thermometer. Microscopic images were taken in a compound microscope (Leica, Germany). 


\section{Results ANd Discussion}

Two Cochlodinium species were identified in the samples collected monthly from Bahía de La Paz during spring 2011. Cochlodinium convolutum was found in bottle and net samples; its abundance ranged between 400-2200 cells $\mathrm{L}^{-1}$. A total of 35 and 42 specimens of $C$. convolutum were counted in horizontal and vertical net samples, respectively, on 24 March 2011. Five, ten and four specimens of $C$. convolutum were found in surface net phytoplankton samples collected on 28 April, 26 May and 26 June 2011, respectively. The specimens fit well with the diagnosis and descriptions of Kofoid \& Swezy (1921) and Matsuoka et al. (2008). Cells of C. convolutum are elongated, ovoid to round and slightly fusiform in shape (Fig. 1A-F) with the anterior end rounded. The epicone becomes slender toward the apex. The Hypocone was rounded, with two broad lobes; the left lobe always larger than the right one. The cingulum circled the cell $\sim 1.5$ times. Cells range from $55-87 \mu \mathrm{m}$ in length and from $34-50 \mu \mathrm{m}$ in width. All specimens of $C$. convolutum occurred as solitary cells. As described in Matsuoka et al. (2008), no visible orange-pigmented body was noted. A rounded rectangular to ellipsoidal nucleus located in the center and the left ventral side of the cell was observed (Fig. 1D). The chloroplasts of C. convolutum are reticulate; many small grains regularly scattered in the cell surface (Figs. 1A, B and F). Twenty-one encysted cells of C. convolutum were in net phytoplankton samples (Fig. 1D-F). Some temporary cysts have two hyaline membranes (Fig. 1D). Salinity was 34.5 psu. Sea water temperature was $21.0-24.5^{\circ} \mathrm{C}$, coinciding with that reported by Kofoid \& Swezy (1921) off La Jolla, California when $C$. convolutum was found. Matsuoka et al. (2008) reported $26-27^{\circ} \mathrm{C}$, suggesting that this taxon is a warm-temperate to tropical species.

There are few records of Cochlodinium convolutum in the literature. This species was first found in a surface net sample taken near La Jolla on 27 July 1914. Additional collections were made on 20 July 1917 in samples collected 23.6 miles off La Jolla ( $80 \mathrm{~m}$ vertical net haul) and on 6 August 1917, 4 miles offshore (60 m vertical net haul) (Kofoid \& Swezy 1921). About 90 years later, $C$. convolutum was reported as a red tide in several coastal lagoons of western Japan (Matsuoka et al. 2008), and also this species has been recorded in Shimoda Bay, Japan $\left(34^{\circ} 39.52 \mathrm{~N}, 138^{\circ} 572 \mathrm{E}\right)^{1}$.

Seventeen and six specimens of Cochlodinium helicoides were examined in the net phytoplankton samples collected on April 28 and May 26 2011, respectively. This species was not found in bottle samples. C. helicoides cells are irregularly sub-ovoidal, broad, and posteriorly asymmetrical (Fig. 2A-D). The anterior end is tapering; the posterior end is broad, the postero-ventral face drawn out into a flap-like extension on its right side, giving the body a sinistro-ventral excavation, with the dorsal side strongly convex. The epicone and hypocone were subequal in size. The hypocone was broader than the epicone, less symmetrical with the dextroventral face drawn out into an outstanding flap or lobe, still further posteriorly marked by a deep sulcal notch. The girdle represents a descending left spiral of 1.5 turns. The sulcus invades the epicone in a short loop which may partly encircle the apex or may terminate below the right side of the cell. The nucleus is central. C. helicoides are yellow, usually with chloroplasts. All specimens of $C$. helicoides occurred as solitary cells. Three specimens were observed enclosed in a thin hyaline temporary cyst (Fig. 2C). Cells are $43-67 \mu \mathrm{m}$ long and $\approx 30-36 \mu \mathrm{m}$ wide.

There are few records of $C$. helicoides in the literature. This species was first defined by Lebour (1925) for the organism which was called Cochlodinium helix by Kofoid \& Swezy (1921) and which was shown in one of Schütt's figures in 1895 (Dodge 1982). Kofoid \& Swezy (1921) reported specimens of C. helicoides (as C. helix) collected on July 27 and August 15, 1917 off La Jolla, California. Lackey \& Clendenning (1965) reported C. helicoides (as Gymnodinium helicoides) during an oceanographic survey in July-August 1959 off Ballast Point, near San Diego Bay, California. The species was reported elsewhere: in Plymouth Sound, England (Dodge 1982); in the South China Sea (Yan et al. 2002); Odessa Bay in the Black Sea (Terenko 2005); and Chesapeake Bay (Marshall et al. 2005). In this study, temperature was $21.0-24.5^{\circ} \mathrm{C}$. This species has been reported in a temperature range between $0.5^{\circ} \mathrm{C}$ (Terenko 2005) to $21.9^{\circ} \mathrm{C}$ (Kofoid \& Swezy 1921).

Monitoring microalgae species forming red tides, by studying live specimens, has been performed since 2000 in Bahía de La Paz (Gárate-Lizárraga et al. 2004). Since that time, $C$. helicoides has been observed only on March 24, May 262011 and C. convolutum on March 24, April 28, May 26 and June 262011 in Bahía de La Paz. The morphology of $C$. convolutum and $C$. helicoides changes during observation under a light microscope. Likewise, cells tend to form a hyaline membrane around the cell or a temporary hyaline cyst, otherwise they explode. Lugol fixed specimens of these species could not be properly identified. Live phytoplankton samples are important in the study of naked dinoflagellates.

1<http://www.biol.tsukuba.ac.jp/ algae/PS/Dinophyta/Cochlodinium_convolutum/index.html> 


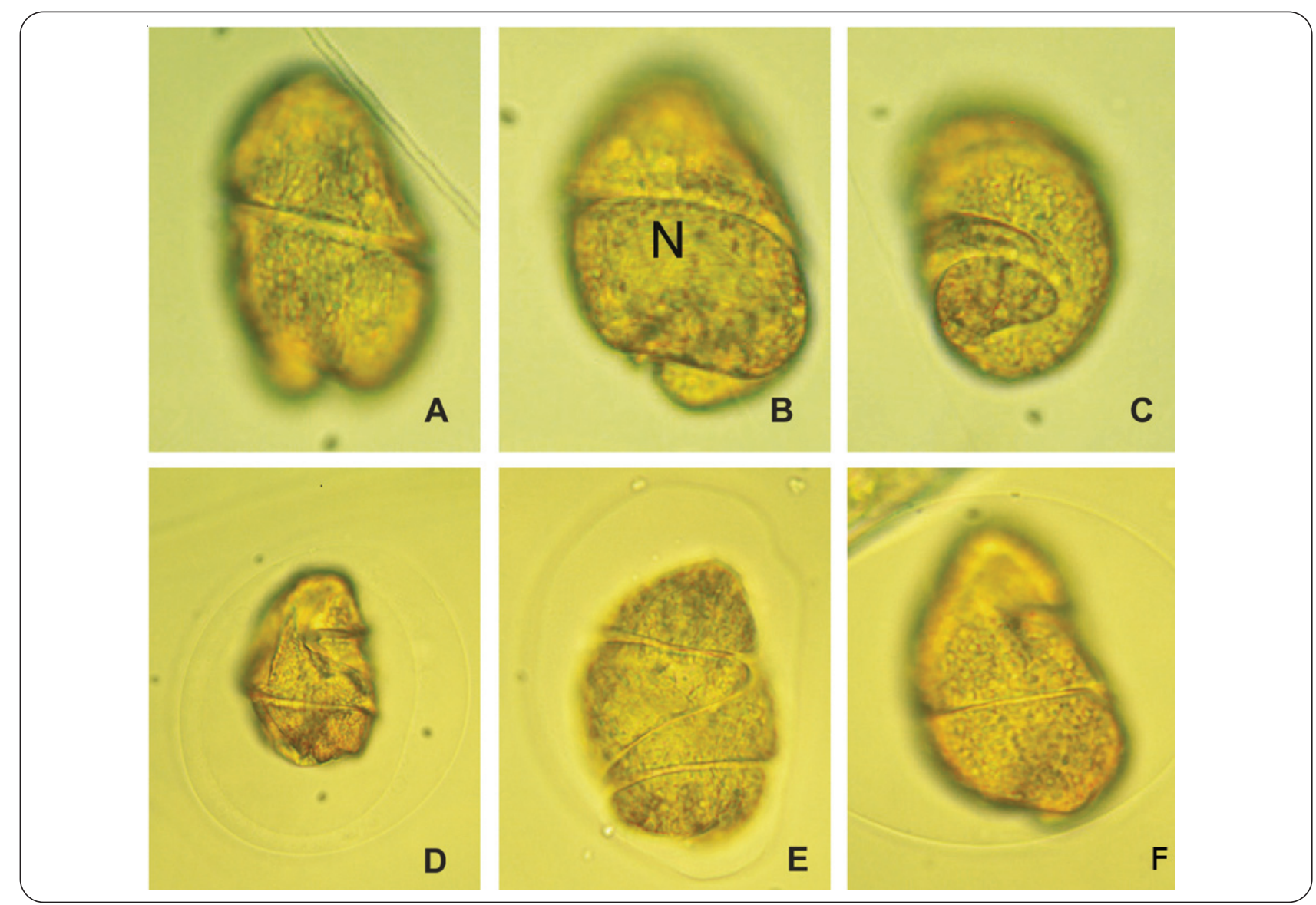

Figure 1. A-F. Microphotographs of Cochlodinium convolutum found in Bahía de La Paz during spring 2011. A) Specimen of C. convolutum in right lateral view. B) Cell showing the nucleus (N). C) Cell showing the antapical end. D) Temporary cyst clearly shows two hyaline membranes around the cell. E and F) Temporary cysts found on April 28 and May 242011 , respectively / A-F. Microfotografías de especímenes de Cochlodinium convolutum encontrados en la Bahía de La Paz durante la primavera de 2011. A) Espécimen de C. convolutum en vista lateral derecha. B) Célula mostrando el núcleo (N). C) Célula mostrando el extremo antapical. D) Quiste temporal que muestra claramente dos membranas hialinas alrededor de la célula. E y F) Quistes temporales encontrados el 28 de abril y el 24 de mayo de 2011, respectivamente

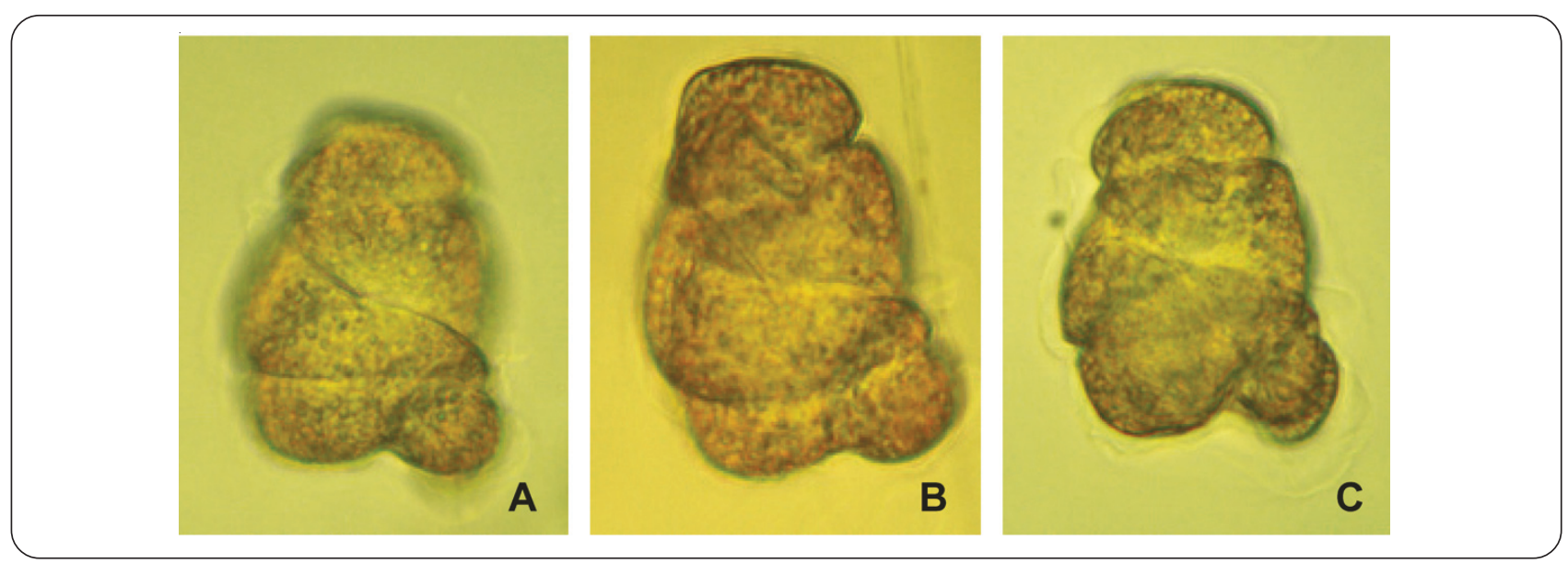

Figure 2. Microphotographs of Cochlodinium helicoides. A-B) Specimens viewed from right side. C) Specimen of $C$. helicoides showing the hyaline membrane around the cell (temporary cyst) / Microfotografías de Cochlodinium helicoides. A-B) Especímenes vistos de lado derecho. C) Espécimen de $C$. helicoides mostrando una membrana hialina alrededor de la célula (quiste temporal) 


\section{ACKnowledgments}

We are very grateful to Yuri Okolodkov (Universidad Veracruzana) for his commentaries to a former manuscript. We also thank two anonymous referees for their helpful comments and suggestions. The projects were funded by Instituto Politécnico Nacional (SIP-20110281, SIP20110139 and SIP-20110590). I.G.L. and F.G.D. are COFAA and EDI fellows.

\section{LITERATURE CITED}

Cortés-Lara MC, R Cortés-Altamirano \& AP SierraBeltrán. 2004. Presencia de Cochlodinium catenatum (Gymnodinales: Gymnodinaceae) en mareas rojas de Bahía Banderas, Pacífico Mexicano. Revista de Biología Tropical 52(Supl. 1): 35-50.

Dodge JD. 1982. Marine dinoflagellates of the British Isles, 303 pp. Her Majesty's Stationery Office, London.

Gárate-Lizárraga I, DJ López-Cortés, JJ BustillosGuzmán \& FE Hernández-Sandoval. 2004. Blooms of Cochlodinium polykrikoides (Gymnodiniaceae) in the Gulf of California, Mexico. Revista de Biología Tropical 52 (Supl. 1): $51-58$.

Gárate-Lizárraga I, CJ Band-Schmidt, F Aguirre-Bahena \& T Grayeb-del Álamo. 2009a. A multi-species microalgae bloom in Bahía de La Paz, Gulf of California, Mexico (June 2008). CICIMAR Oceánides 24(1): 1-15.

Gárate-Lizárraga I, JA Díaz-Ortiz, B Pérez-Cruz, M AlarcónTacuba, A Torres-Jaramillo, MA Alarcón-Romero \& S López-Silva. 2009b. Cochlodinium polykrikoides and Gymnodinium catenatum in Bahía de Acapulco, Mexico (20052008). Harmful Algae News 40: 8-9.

Gómez F. 2005. A list of dinoflagellates in the world's oceans. Acta Botanica Croatica 64: 129-212.

Iwataki M, H Kawami \& K Matsuoka. 2007. Cochlodinium fulvescens sp. nov. (Gymnodiniales, Dinophyceae), a new chain forming unarmored dinoflagellate from Asian coasts. Phycological Research 55: 231-239.
Kofoid CA \& O Swezy. 1921. The free-living unarmored dinoflagellata. Memoirs of the University of California, 562 pp. Univesity of California Press, Berkeley.

Lackey JB \& KA Clendenning. 1965. Ecology of the microbiota of San Diego Bay, California. Transactions of the San Diego Society of Natural History 14(2): 9-40.

Lebour MV. 1925. The dinoflagellates of Northern seas, 250 pp. Marine Biological Association of the United Kingdom, Plymouth.

Marshall HG, L Burchardt \& R Lacouture. 2005. A review of phytoplankton composition within Chesapeake Bay and its tidal estuaries. Journal of Plankton Research 27: 10831102.

Matsuoka K, M Iwataki \& H Kawami. 2008. Morphology and taxonomy of chain-forming species of the genus Cochlodinium (Dinophyceae). Harmful Algae 7: 261-270.

Morales-Blake A, C Cavazos-Guerra \& D HernándezBecerril. 2001. Unusual HABs in Manzanillo Bay, Colima, Mexico. Harmful Algae News 22: 6.

Morquecho-Escamilla ML \& R Alonso-Rodríguez. 2008. First record of Cochlodinium fulvescens in Mexican Pacific. Harmful Algae News 37: 5-6.

Okolodkov YB \& I Gárate-Lizárraga. 2006. An annotated checklist of dinoflagellates (Dinophyceae) from the Mexican Pacific. Acta Botanica Mexicana 74:1-154.

Terenko L. 2005. New dinoflagellate (Dinoflagellata) species from the Odessa Bay of the Black Sea. Oceanological and Hydrobiological Studies 37(Suppl. 3): 205-216.

Yan T, Z Ming-Jiang \& Z Jing-Zhong. 2002. A national report on harmful algal blooms in China. In: Taylor FJR \& VL Trainer (eds). Harmful algal blooms in the PICES region of the North Pacific. PICES Scientific Report 23: 119-128. North Pacific Marine Science Organization, Sidney. 